\title{
The Derivatives Market: Efficiency and Speculation
}

\author{
Carla Barracchini (Corresponding author) \\ Associate professor, Dept. of Systems and Institutions for Economics \\ Univesità degli Studi delL'Aquila L'Aquila, Italy \\ E-mail: carla.barracchini@ec.univaq.it
}

Maria Elena Addessi

Economics Faculty, Libera Università degli Studi Maria SS Assunta (LUMSA), Rome, Italy

E-mail: m.addessi@lumsa.it

Received: December 5, 2011 Accepted: December 21, $2011 \quad$ Published: March 1, 2012

doi:10.5539/jms.v2n1p87 URL: http://dx.doi.org/10.5539/jms.v2n1p87

\begin{abstract}
Derivatives, as it is well known, are used in hedging transactions, as well as in speculative ones. Some types of pricing are made for speculative or even criminal purposes: Russell Sage (1816-1906), US financier. A variety of measures such as the Jensen's Alpha, the Sharpe Index and the Value at Risk, commonly used in portfolio evaluation, are misleading in presence of derivatives. The hidden risk may suddenly have dramatic consequences (Barone Adesi, G. (2004)). From this perspective, this paper does not consider information asymmetry but aims at showing how, through derivatives and options in particular, it is possible to build strategies that are independent from the trend of underlying assets. This feature was at first proved in Barone, E.- Olivieri, G. (2009) and is investigated much more in details in this study.
\end{abstract}

Keywords: Derivatives, Efficiency, Usury loan, Information asymmetry, Risk-free rate, Box-spread, Bullish spread

\section{Introduction}

Derivatives, as it is well known, are used in hedging transactions, as well as in speculative ones. The theory provides all the techniques which, without arbitrage, allow for fair pricing. Most often, however, in the practice of trading transactions, the theoretical predictions are not fulfilled, not because the models do not work but because the simplifying assumptions do not take into account the continuous evolution of the initial conditions (Barone Adesi, G. (2004)).

There are many studies (for a detailed analysis of the studies carried out on market efficiency, see Barucci, E. (2002)) on market efficiency, but it is not easy to summarize them. Moreover, the present work does not claim to be thorough.

Market inefficiency is in some cases attributed to an incorrect determination of the risk-free rate and to the assumption that volatility of the underlying asset is a function of its historical volatility.

In other cases, as history has shown, some types of pricing are made for speculative or even criminal purposes: Russell Sage (1816-1906), US financier.

In classical models, used for educational purposes by now, the quantities to be considered are the following: the volatility of the underlying asset, the risk-free rate, the expected return and the price distribution of the underlying asset which, in most cases, is assumed to be normal. In the evaluation of portfolios containing derivatives, only a detailed knowledge of their composition may reveal their hidden dangers (Barone, E. (2003)).

A variety of measures such as the Jensen's Alpha, the Sharpe Index and the Value at Risk, commonly used in portfolio evaluation, are misleading in presence of derivatives. The hidden risk may suddenly have dramatic consequences (Barone Adesi, G. (2004)). From this perspective, this paper does not consider information asymmetry but aims at showing how, through derivatives and options in particular, it is possible to build 
strategies that are independent from the trend of underlying assets. This feature was at first proved in Barone, E. - Olivieri, G. (2009) and is investigated much more in details in this study.

\section{Strategies with options}

Before generalizing the strategies suggested by Barone-Olivieri (2009), we need to explain the notations for some quantities that will be used over this work:

$B_{t}\left(h_{l}, h_{2}, h_{3}, \ldots, h_{n}\right)$ stands for the pay off of the financial transaction which, in our case, is a zero coupon bond at time $\mathrm{t}$ and referring to the variables $h_{1}, h_{2}, h_{3}, \ldots, h_{n}$.

$i\left(h_{1}, h_{2}, h_{3}, \ldots, h_{n}\right)$ stands for the interest rate over a given period, in the interval $[0, \mathrm{~T}]$ of the financial transaction which, in our case, is a zero coupon bond at time $t$ and referring to the variables $h_{1}, h_{2}, h_{3}, \ldots, h_{n}$.

Furthermore, if the payoff is constant at time $t$ it is denoted with $B_{t, .}$. The same notation will be used for the interest rate.

\subsection{Underlying asset, call option, put option}

In the scheme proposed in Barone, E. - Olivieri, G. (2009), a financial transaction has been built. Such a transaction appears to be a seemingly random combination of a security (simply speaking, an equity) and two options, put and call - the latter built on the same underlying asset whose price is denoted with $\mathrm{S}_{\mathrm{t}}$, the same strike with $\mathrm{K}$ and the same maturity with $\mathrm{T}$ (also called range of the operation $[0, \mathrm{~T}]$ ). The proposed scheme is in Table 1 and therefore the financial transaction becomes a zero coupon bond, whose pay offs at $\mathrm{t}=0$ and $\mathrm{t}=\mathrm{T}$ are, respectively, $B_{0}$ and $B_{T}$ as shown in Table 2 .

The interest rate of such a transaction appears linearly growing and depending on the strike price $\mathrm{K}$ :

$$
i(K)=\frac{B_{T}}{B_{0}}-1=\frac{K}{S_{0}-C_{0}+P_{0}}-1
$$

We are now going to examine the interest rate as a function, supposing that the options have the same underlying asset but different strike prices. Respectively indicating the strike call and the strike put with $\mathrm{K}_{\mathrm{C}}$ and $\mathrm{K}_{\mathrm{P}}$, we can distinguish two cases:

a) $\mathrm{K}_{\mathrm{C}}<\mathrm{K}_{\mathrm{P}}$

b) $\mathrm{K}_{\mathrm{C}}>\mathrm{K}_{\mathrm{P}}$

2.1.1 Underlying asset, call option, put option when $\mathrm{K}_{\mathrm{C}}<\mathrm{K}_{\mathrm{P}}$

In this case, Table 1 becomes Table 3 . The value of bonds at $t=0, B_{0}$, remains unchanged $\left(B_{0}=C_{0}+S_{0}-P_{0}\right)$, while at $\mathrm{t}=\mathrm{T}$ it is a function that not only depends on the two strikes, but also on the value of the underlying asset at maturity. The pay off replicates a downward spread. In fact:

$$
B_{T}\left(S_{T}, K_{C}, K_{P}\right)=\left\{\begin{array}{lll}
K_{P} & \text { se } & S_{T}<K_{C} \\
K_{C}+K_{P}-S_{T} & \text { se } & K_{C}<S_{T}<K_{P} \\
K_{C} & \text { se } & K_{P}<S_{T}
\end{array}\right.
$$

Unlike the case of a single strike price K, as already described in Barone, E.- Olivieri, G. (2009) , in this study the interest rate over a given period is not a constant but depends on the value of the underlying asset at maturity. Even if it is not constant, the interest rate as a function is limited and has a performance similar to that of the spread. In fact:

$$
i\left(S_{T}, K_{C}, K_{P}\right)=\left\{\begin{array}{lll}
\frac{K_{P}}{B_{0}}-1 & \text { se } & S_{T}<K_{C} \\
\frac{K_{C}+K_{P}-S_{T}}{B_{0}} & \text { se } & K_{C}<S_{T}<K_{P} \\
\frac{K_{C}}{B_{0}}-1 & \text { se } & K_{P}<S_{T}
\end{array}\right.
$$

2.1.2 Underlying asset, call option, put option when $\mathrm{K}_{\mathrm{C}}>\mathrm{K}_{\mathrm{P}}$

In this case, the pay off is a bullish spread, see Table 4. 


$$
B_{T}\left(S_{T}, K_{C}, K_{P}\right)=\left\{\begin{array}{lll}
K_{P} & \text { se } & S_{T}<K_{C} \\
S_{T} & \text { se } & K_{C} \leq S_{T}<K_{P} \\
K_{C} & \text { se } & K_{P} \leq S_{T}
\end{array}\right.
$$

and therefore there are two possible values of the return rate over a given period:

$$
i\left(S_{T}, K_{C}, K_{P}\right)=\left\{\begin{array}{lll}
\frac{K_{P}}{B_{0}}-1 & \text { se } & S_{T}<K_{C} \\
\frac{S_{T}}{B_{0}}-1 & \text { se } & K_{C} \leq S_{T}<K_{P} \\
\frac{K_{C}}{B_{0}}-1 & \text { se } & K_{P} \leq S_{T}
\end{array}\right.
$$

It is immediately evident that - suitably "playing" with the appropriate constants of the system, with the strike price and the initial value of the options - a reformulation of the interest rate is possible, depending on the needs of the operator. If a more complex financial transaction is built, it becomes easier to hide one's own speculative purposes.

\subsection{Box spread}

In order to build the box spread, put and call options are used in the long and short positions, as shown in Table 5. In such a case, the cash flows of the bond are in Table 6 .

and therefore the interest rate over a given period is constant - i.e. it does non depend on the value of the underlying asset at maturity

$$
i=\frac{K_{2}-K_{1}}{B_{0}}-1
$$

We are now going to analyze the case where the box spread considers four, instead of two, possible values of the strike. In order to make such a generalization, it is necessary to consider four options built on the same underlying asset but with different strikes. The notations are shown in Table 7.

The performance of the derivative - and this is the point, because we are dealing with a composition of derivatives - is shown in the following Graphics 1-24, with reference to all the possible combinations of strike prices.

In some cases the pay off at maturity is always non-negative; in others it is always non-positive and in others the function that represents it is monotone with a maximum and a minimum of conflicting signs. What is interesting to highlight is that, in all cases, there is a limited pay off and the spread over the interest rate is consequently known. As Barone-Olivieri (2009) brilliantly explained, if the strike values and, as we suggest, even the premiums vary, any transaction can be built making it convenient for one of the parties involved. If the options' issuer is the creditor himself, the malice is obvious; but if you play with different issuers, the possibility of making a profit lies in the ability of the operator to carry on a transaction.

\section{Conclusion}

Market inefficiency is due to a lack of calibration of the risk-free rate, to the volatility or to other random components that do not depend on the portfolio manager's will. In other cases, such as in the Sage Russel one, the inefficiency is "built" ex ante - but this hypothesis seems unfair in our opinion. We believe that, as we have shown using simple arguments, laws on credit should take into account "those contracts, synthetic loans, i.e. those transactions which are - in substance, even if not in the form - equivalent to usurious loans" (Knoll M.S. (2002)). Derivatives, in their widely recognized role of hedging market risks, may however, if suitably used, play the role of a weapon in credit illegitimate contracts with usurious and speculative purposes.

\section{References}

Alessandri Piergiorgio. (2011). Azzardo morale e crisi finanziaria del 2007/2008. working paper.

Ambrose, B.W., Benjamin, J., and Chinloy P. (1996). Credit Restrictions and the Market for Commercial Real Estate Loans. Real Estate Economics, 24:1, pp.1-22. http://dx.doi.org/10.1111/1540-6229.00677

Barone Adesi, G. (2004). Performance and derivatives: hidden dangers. National Centre of Competence in Research Financial Valuation and Risk Management, n1: pp 11. 
Barone, E. (2003). Derivati complessi come portafogli di attività elementari. SanPaolo IMI, Torino.

Barone, E.- Olivieri, G. (2009). Derivati ed usura: l'utilizzo delle opzioni nella costruzione di negozi in frode alla legge. Rivista trimestrale di diritto dell'economia, rassegna di dottrina e giurisprudenza, 1: pp. 110-124.

Barucci, E. (2002). Financial markets Theory. Springer and Verlag.

Bianchi T. (1989). L'arte del banchiere. Edibank, Milano, p.13, ss.

Collett, D., Lizieri, C., and Ward C. (2003). Timing and the Holding Periods of Institutional Real Estate. Real Estate Economics, 31:2, pp. 205-222. http://dx.doi.org/10.1111/1540-6229.00063

Cunningham D., \& Capone, C. (1990). The Relative Termination Experience of Adjustable to Fixed-Rate Mortgages. Journal of Finance, 45, 1687-1703. http://dx.doi.org/10.2307/2328759

Danny Ben-Sharar (2006). Screening Mortgage Default Risk: A Unified Theoretical Framework. Journal of Real Estate Research, Vol. 28, n. 3.

Duen-Li Kao (2000). Estimating and Pricing Credit Risk: An Overview. Financial Analysts Journal, 56:4, p.50. http://dx.doi.org/10.2469/faj.v56.n4.2373

Fama, E., and French, K. (1988). Permanent and Temporary components of Stock Prices. Journal of Political Economy, 96, pp.246-273. http://dx.doi.org/10.1086/261535

Gallant, R. P., and Tauchen, G. (1992). Stock prices and volume. Review of Financial Studies, 5, pp.199-242. http://dx.doi.org/10.1093/rfs/5.2.199

Granger, C.W.J. (1969). Investigating causal relations by econometric models and cross-spectral methods. Econometrica, 37 (3), 424-438. http://dx.doi.org/10.2307/1912791

Holod, Dmytro, and Joe Peek. (2007). Asymmetric Information and Liquidity Constraints: A New Test. Journal of Banking and Finance, 31, 2425-51. http://dx.doi.org/10.1016/j.jbankfin.2006.11.012

Holod, Dmytro, and Joe Peek. (2010). Capital Constraints, Asymmetric Information, and Internal Capital Markets in Banking: New Evidence. Journal of Money, Credit, and Banking, 42(5), 879-906. http://dx.doi.org/10.1016/j.jbankfin.2006.11.012

Kelly, J.L. Jr. (1956). A new interpretation of information rate. Bell Syst. Techn. J. 35.

Knight, J.R., Sirmans, C.F., Gelfand, A.E., and Ghosh, S.K. (1998). Analyzing Real Estate Data Problems Using the Gibbs Sampler. Real Estate Economics, 26:3, pp. 469-492. http://dx.doi.org/10.1111/1540-6229.00753

Knoll M.S. (2002). Put-Call Parity and the Law. Cardozo Law Review, vol. 24, no.1, pp. 61-91.

Marsha J. Courchane (2007). The Pricing of Home Mortgage Loans to Minority Borrowers: How Much of the APR Differential Can We Explain? Journal of Real Estate Research, Vol. 29, n. 4.

Minenna, M. (2002). Inside Insider trading. Risk, March 2002, pp.93-97.

Minenna, M. (2003a). Insider trading, abnormal return and preferential information: supervising through a probabilistic model. Journal of Banking and Finance, 27 pp.59-86. http://dx.doi.org/10.1111/1540-6229.00753

Minenna, M. (2003b). The detection of market abuse on financial markets: a quantitative approach, Consob. Quaderni di Finanza, n.54.

Table 1. Underlying asset price $S_{t}$, with $t$ in $[0, T]$

\begin{tabular}{|c|c|c|}
\hline \multirow{2}{*}{ Time t=0 } & \multicolumn{2}{|c|}{ Time $\mathbf{t}=\mathbf{T}$} \\
\cline { 2 - 3 } & $\mathbf{S}_{\mathbf{T}}<\mathbf{K}$ & $\mathbf{K} \leq \mathbf{S}_{\mathbf{T}}$ \\
\hline $\mathrm{S}_{0}$ & $\mathrm{~S}_{\mathrm{T}}$ & $\mathrm{S}_{\mathrm{T}}$ \\
\hline$-\mathrm{C}_{0}$ & 0 & $-\left(\mathrm{S}_{\mathrm{T}}-\mathrm{K}\right)$ \\
\hline $\mathrm{P}_{0}$ & $-\left(\mathrm{S}_{\mathrm{T}}-\mathrm{K}\right)$ & 0 \\
\hline
\end{tabular}

Table 2. Pay off

\begin{tabular}{|c|c|}
\hline Time & Pay off \\
\hline 0 & $B_{0}=S_{0^{-}} C_{0}+P_{0}$ \\
\hline $\mathrm{T}$ & $B_{T}=K$ \\
\hline
\end{tabular}


Table 3. Underlying asset, call option, put option when $\mathrm{KC}<\mathrm{KP}$

\begin{tabular}{|c|c|c|c|}
\hline \multirow{2}{*}{ Time t=0 } & \multicolumn{3}{|c|}{ Time t=T } \\
\cline { 2 - 4 } & $\mathbf{S}_{\mathbf{T}}<\mathbf{K}_{\mathbf{C}}$ & $\mathbf{K}_{\mathbf{C}} \leq \mathbf{S}_{\mathbf{T}}<\mathbf{K}_{\mathbf{P}}$ & $\mathbf{K}_{\mathbf{P}} \leq \mathbf{S}_{\mathbf{T}}$ \\
\hline $\mathrm{S}_{0}$ & $\mathrm{~S}_{\mathrm{T}}$ & $\mathrm{S}_{\mathrm{T}}$ & $\mathrm{S}_{\mathrm{T}}$ \\
\hline$-\mathrm{C}_{0}$ & 0 & $-\left(\mathrm{S}_{\mathrm{T}}-\mathrm{K}_{\mathrm{C}}\right)$ & $-\left(\mathrm{S}_{\mathrm{T}}-\mathrm{K}_{\mathrm{C}}\right)$ \\
\hline $\mathrm{P}_{0}$ & $-\left(\mathrm{S}_{\mathrm{T}}-\mathrm{K}_{\mathrm{P}}\right)$ & $-\left(\mathrm{S}_{\mathrm{T}}-\mathrm{K}_{\mathrm{P}}\right)$ & 0 \\
\hline
\end{tabular}

Table 4. Bullish spread

\begin{tabular}{|c|c|c|c|}
\hline \multirow{2}{*}{ Time t=0 } & \multicolumn{3}{|c|}{ Time t=T } \\
\cline { 2 - 4 } & $\mathbf{S}_{\mathbf{T}}<\mathbf{K}_{\mathbf{P}}$ & $\mathbf{K}_{\mathbf{P}} \leq \mathbf{S}_{\mathbf{T}}<\mathbf{K}_{\mathbf{C}}$ & $\mathbf{K}_{\mathbf{C}} \leq \mathbf{S}_{\mathbf{T}}$ \\
\hline $\mathrm{S}_{0}$ & $\mathrm{~S}_{\mathrm{T}}$ & $\mathrm{S}_{\mathrm{T}}$ & $\mathrm{S}_{\mathrm{T}}$ \\
\hline$-\mathrm{C}_{0}$ & 0 & 0 & $-\left(\mathrm{S}_{\mathrm{T}}-\mathrm{K}_{\mathrm{C}}\right)$ \\
\hline $\mathrm{P}_{0}$ & $-\left(\mathrm{S}_{\mathrm{T}}-\mathrm{K}_{\mathrm{P}}\right)$ & 0 & 0 \\
\hline
\end{tabular}

Table 5. Box spread

\begin{tabular}{|c|c|c|c|c|}
\hline \multirow{2}{*}{ Option } & \multirow{2}{*}{$\begin{array}{c}\text { Time } \\
\mathbf{t}=\mathbf{0}\end{array}$} & $\mathbf{S}_{\mathbf{T}}<\mathbf{K}_{\mathbf{1}}$ & $\mathbf{K}_{\mathbf{1}} \leq \mathbf{S}_{\mathbf{T}}<\mathbf{K}_{\mathbf{2}}$ & $\mathbf{K}_{\mathbf{2}} \leq \mathbf{S}_{\mathbf{T}}$ \\
\cline { 3 - 5 } & $\mathrm{C}_{1}$ & 0 & $\mathrm{~S}_{\mathrm{T}}-\mathrm{K}_{1}$ & $\mathrm{~S}_{\mathrm{T}^{-}}-\mathrm{K}_{1}$ \\
\hline Call long with strike $\mathrm{K}_{1}$ & $-\mathrm{C}_{2}$ & 0 & 0 & $-\left(\mathrm{S}_{\mathrm{T}^{-}} \mathrm{K}_{2}\right)$ \\
\hline Call short with strike $\mathrm{K}_{2}$ & $-\mathrm{P}_{1}$ & $-\left(\mathrm{K}_{1}-\mathrm{S}_{\mathrm{T}}\right)$ & 0 & 0 \\
\hline Put short with strike $\mathrm{K}_{1}$ & $\mathrm{P}_{2}$ & $\mathrm{~K}_{2}-\mathrm{S}_{\mathrm{T}}$ & $\mathrm{K}_{2}-\mathrm{S}_{\mathrm{T}}$ & 0 \\
\hline Put long with strike $\mathrm{K}_{2}$ & \multicolumn{4}{|c}{} \\
\hline
\end{tabular}

Table 6. Pay off of box spread

\begin{tabular}{|c|c|}
\hline Time & Pay off \\
\hline 0 & $B_{0}=\left(\mathrm{C}_{1}-\mathrm{C}_{2}\right)-\left(\mathrm{P}_{1}-\mathrm{P}_{2}\right)$ \\
\hline $\mathrm{T}$ & $B_{T}=\mathrm{K}_{2}-\mathrm{K}_{1}$ \\
\hline
\end{tabular}

Table 7. Notations

\begin{tabular}{|c|}
\hline Option \\
\hline Call long with strike $\mathrm{K}_{1}$ \\
\hline Call short with strike $\mathrm{K}_{2}$ \\
\hline Put short with strike $\mathrm{K}_{3}$ \\
\hline Put long with strike $\mathrm{K}_{4}$ \\
\hline
\end{tabular}

Appendix

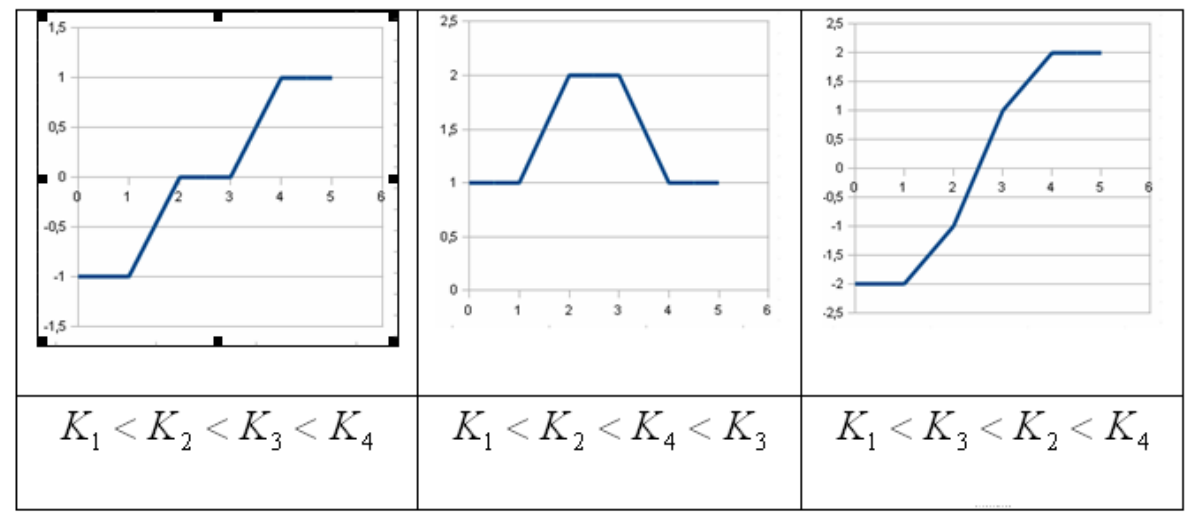

Graphics: 1-2-3 


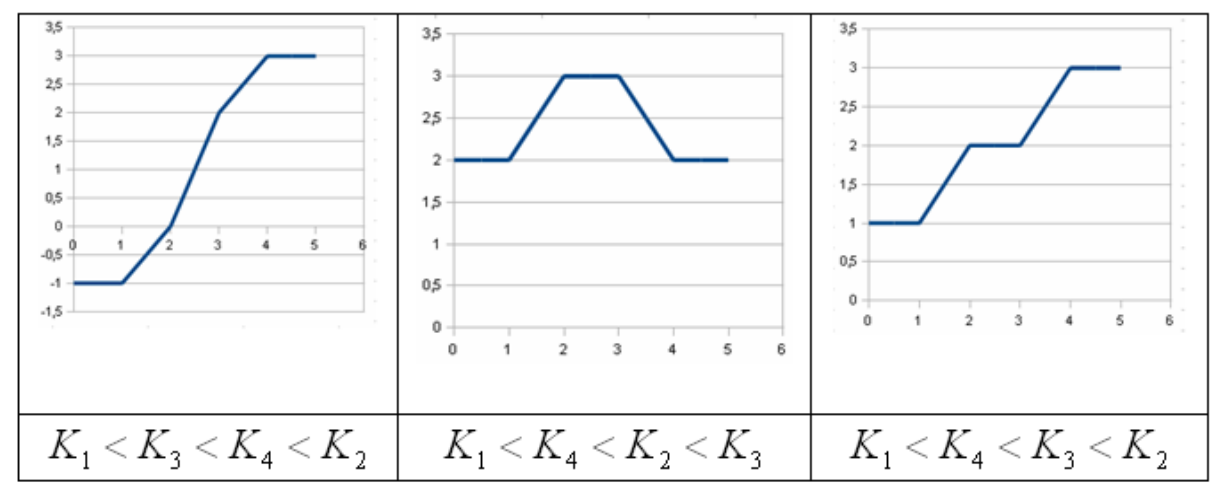

Graphics: 4-5-6

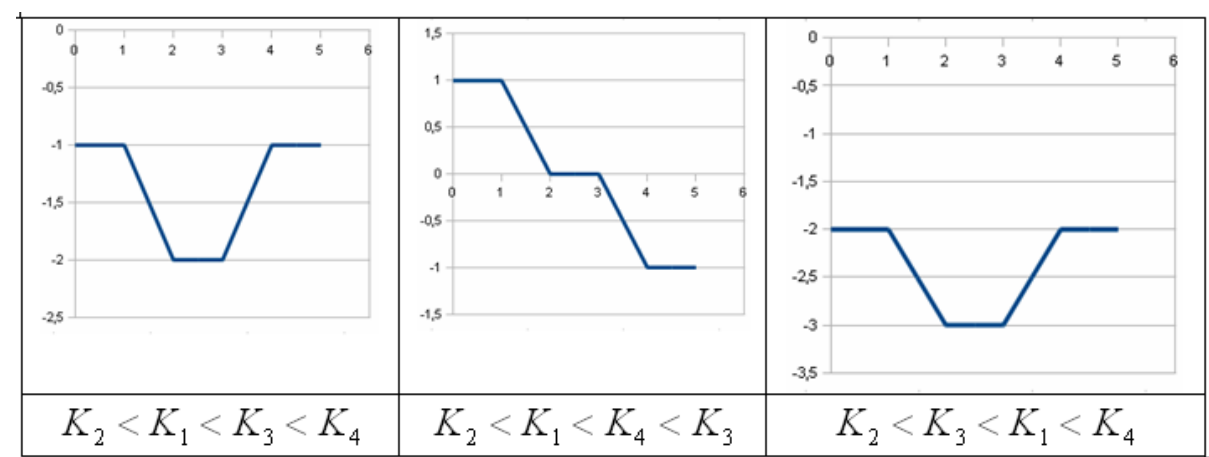

Graphics: 7-8-9

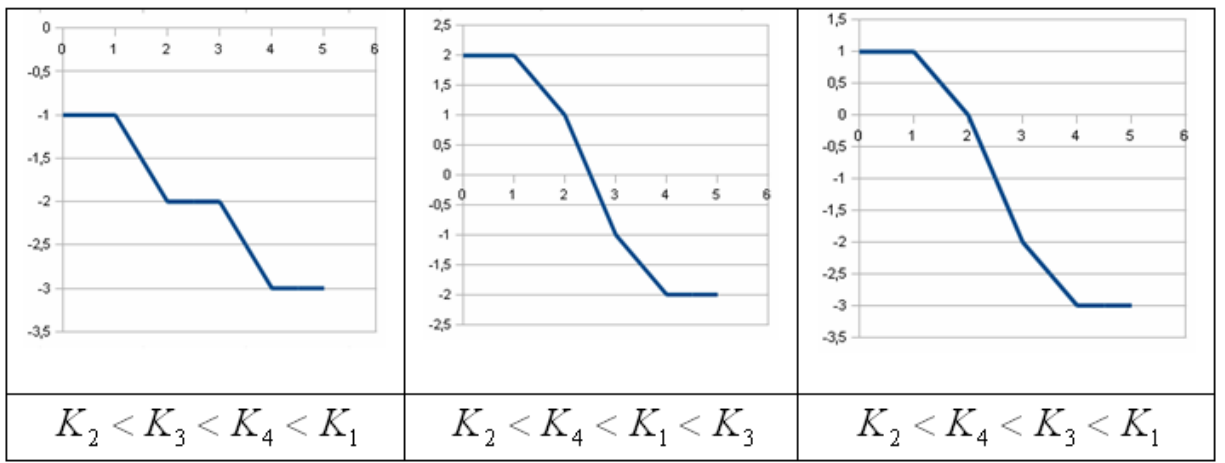

Graphics: 10-11-12

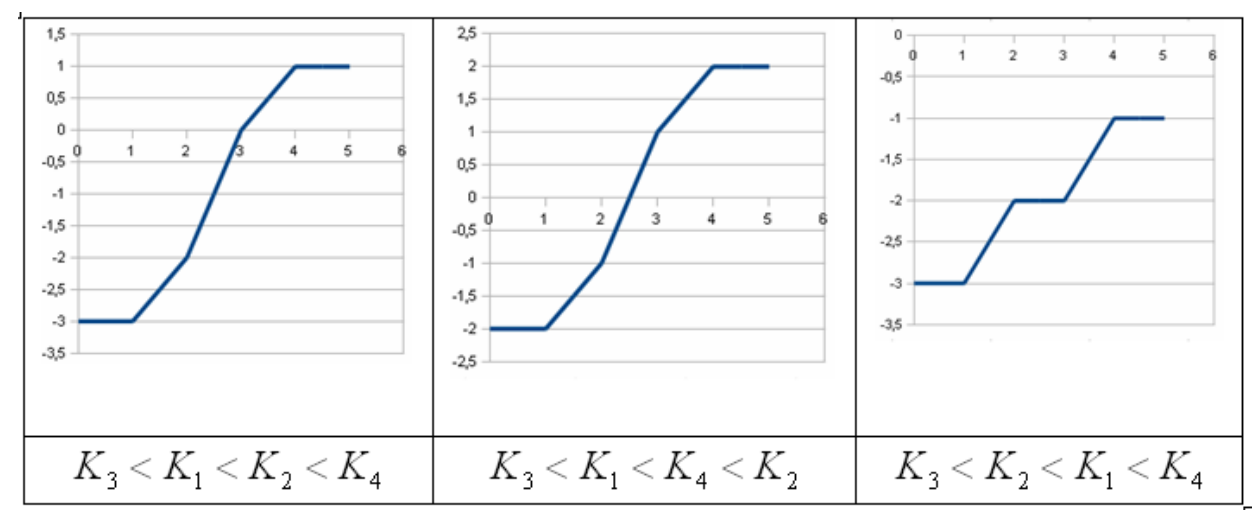

Graphics: 13-14-15 


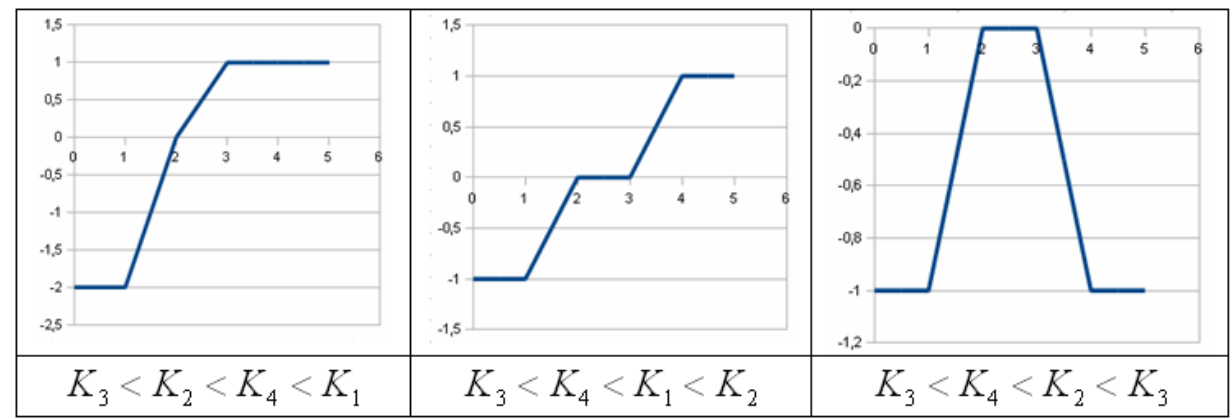

Graphics: 16-17-18

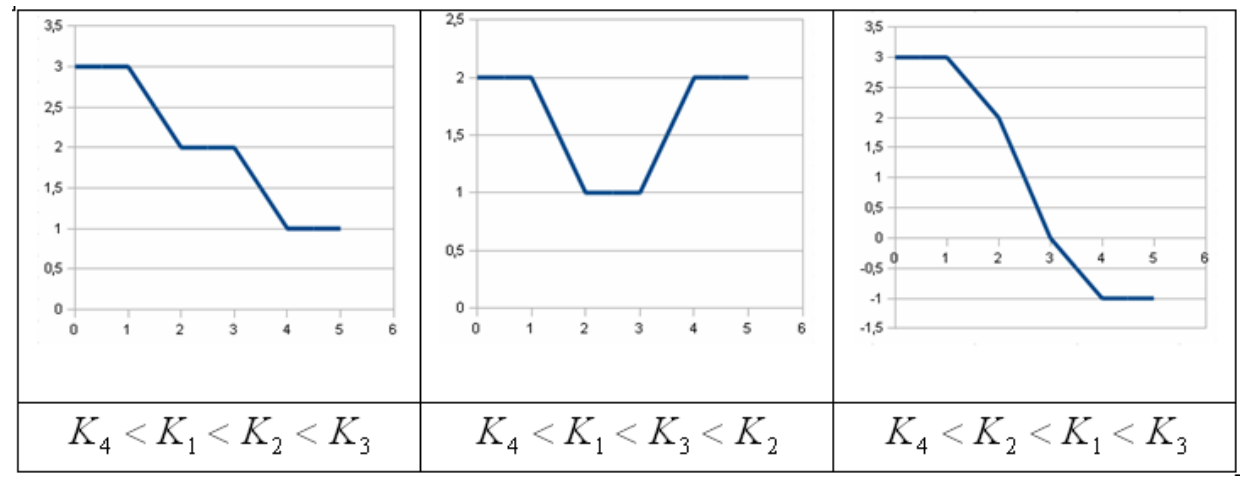

Graphics: 19-20-21

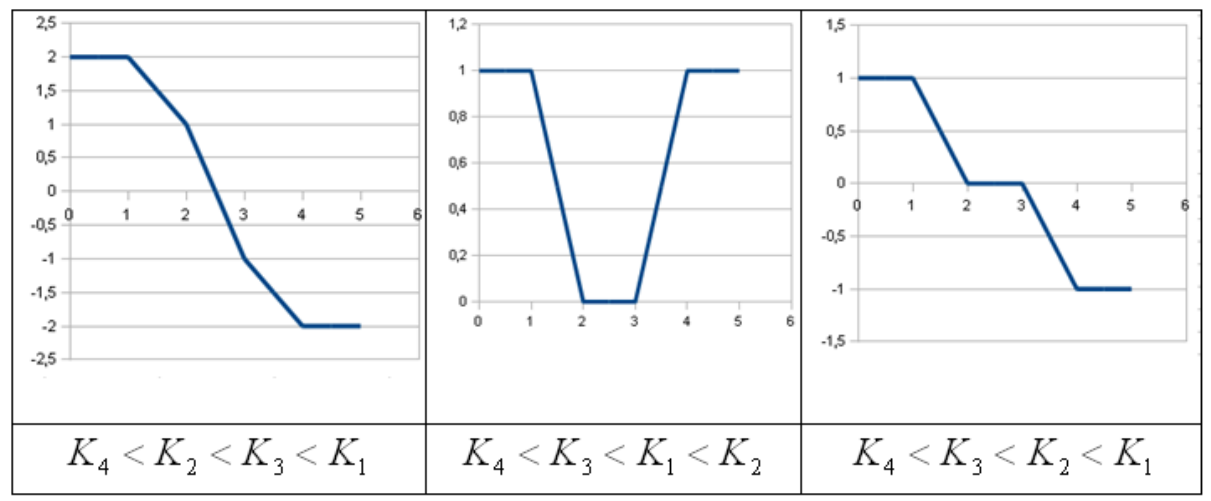

Graphics: 22-23-24 